\title{
Murine monoclonal antibody elicited with antibiotic- exposed Escherichia coli exerts protective capacity in experimental bacterial infections
}

\author{
M. T. LUN, A. M. AMATUCCI, G. RAPONI, F. FILADORO, A. BARTOLAZZI*, R. FRAIOLI*, \\ P. G. NATALI* and C. MANCINI \\ $1^{\circ}$ Cattedra di Microbiologia Clinica, Università "La Sapienza" and * Laboratorio Immunologia, Istituto Regina Elena, \\ Rome, Italy
}

\begin{abstract}
Summary. Escherichia coli pre-exposed to a sub-minimal inhibitory concentration (sub-MIC) of several antibiotics elicits an enhanced humoral response which is protective against challenges with untreated homologous and heterologous bacteria. To characterise the specificity of this response we produced murine monoclonal antibodies (MAbs) to aztreonamtreated E. coli $\mathrm{O} 6: \mathrm{K}$ - This resulted in the identification of $\mathrm{MAb}^{\mathrm{MT}} 1 \mathrm{~F}$, of isotype $\mathrm{IgG}_{1}$, that recognised a $12-\mathrm{kDa}$ protein component of the untreated bacterial cells. After passive transfer, the MAb displayed protective activity in mice infected with lethal doses of live $E$. coli O6: $\mathrm{K}$ - and E. coli $\mathrm{O} 111: \mathrm{B} 4$. In ELISA experiments the MAb cross-reacted with structures located on whole cells of E. coli O6:K-, E. coli O111:B4, E. coli J5 and Salmonella minnesota Re595 and it also exerted a bactericidal activity against live E. coli O6:K-. The modifications induced by antibiotic treatment may unmask bacterial epitopes that may elicit the production of MAbs endowed with protective capacity.
\end{abstract}

\section{Introduction}

Gram-negative bacterial infections are associated with high morbidity and mortality rates despite appropriate antibiotic treatment. ${ }^{1}$ Therefore, interest has arisen as to the possibility of immunotherapy of such infections. ${ }^{2,3}$

A previous study showed that mice immunised with Escherichia coli $\mathrm{O6}: \mathrm{K}$ - pre-exposed to sub-minimal inhibitory concentrations (sub-MICs) of several antibiotics presented enhanced protection towards homologous and heterologous bacterial lethal challenges, compared to mice immunised with untreated bacteria. ${ }^{4}$ This protection was transferred to normal mice through serum of animals immunised with antibiotictreated bacteria, thus suggesting a role for antibodies in the mechanism of protection..$^{5}$ Indeed, in addition to quantitative differences between the immunisation groups, qualitative differences in the antibody reactivity pattern were also observed in the group of mice immunised with antibiotic-treated bacteria.

To gain further insight into the specificity of the protective antibodies, monoclonal antibodies (MAbs) were prepared for use as molecular probes and an examination made of the serological and immuno-

Received 24 Jan. 1994; accepted 29 March 1994. chemical characteristics of MAb MT $1 \mathrm{~F}$, which protected normal animals against lethal challenges with homologous and heterologous bacteria.

\section{Materials and methods}

\section{Bacteria}

E. coli O6:K- (ATCC 25922, Difco Laboratories) was used for immunisation of mice. E. coli $\mathrm{O} 111$ : B4, E. coli J5 and Salmonella minnesota Re595 were a kind gift of Professor J. Verhoef (Eijkman-Winkler Laboratory for Medical Microbiology, University Hospital of Utrecht, The Netherlands).

\section{Immunisation procedure}

E. coli $\mathrm{O} 6: \mathrm{K}-$, grown overnight in Mueller Hinton Broth (Difco) in the presence of $0.5 \times$ MIC of aztreonam (Bristol-Myers Squibb, Rome, Italy) (MIC = $0.078 \mathrm{mg} / \mathrm{L}$ ) was washed three times in sterile saline and resuspended in saline containing formalin $0.2 \%$ to an optical density (OD) equivalent to $10^{9} \mathrm{cfu} / \mathrm{ml}$. The suspension was incubated for $1 \mathrm{~h}$ at $37^{\circ} \mathrm{C}$ and the cells were washed once again in saline. After re-adjustment of the suspension to an optical density equivalent to $10^{9} \mathrm{cfu} / \mathrm{ml}$, amounts were injected into female 


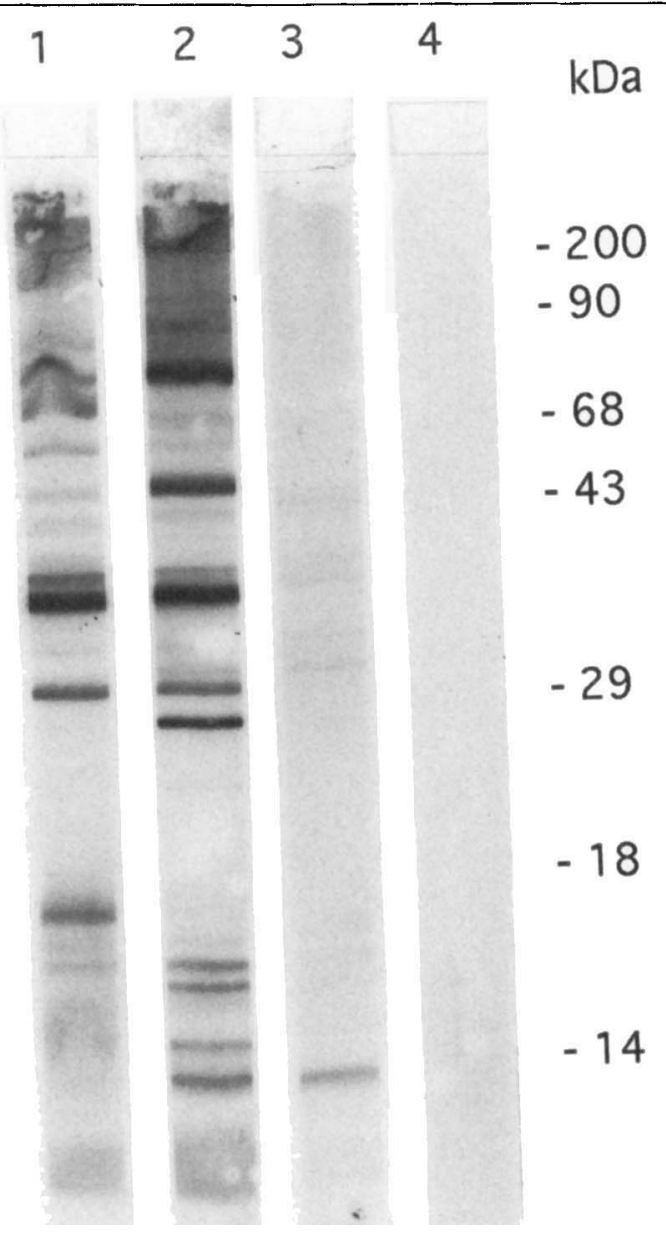

Fig. 1. Immunoblot of $E$. coli $\mathrm{O} 6: \mathrm{K}$ - after reaction with: lane 1, polyclonal sera of mice immunised with untreated $E$. coli $\mathrm{O} 6: \mathrm{K}-; 2$, polyclonal sera of mice immunised with antibiotic-treated $E$. coli $\mathrm{O} 6: \mathrm{K}-; 3$, MAb MT $1 \mathrm{~F} ; \mathbf{4}$, MAb MT IF after digestion of $E$. coli $\mathrm{O} 6: \mathrm{K}$ - with proteinase $\mathrm{K}$.

BALB/c mice according to the following scheme: day $1,10^{7} \mathrm{cfu} /$ mouse; day $7,2 \times 10^{7} \mathrm{cfu} /$ mouse; days 14 , 21,35 and $56,10^{8} \mathrm{cfu} /$ mouse. $^{5}$

\section{Production and selection of hybridomas}

Hybridomas were produced by a slight modification of the method of Fazekas De St Groth and Scheidegger. ${ }^{6}$ Spleen cells from mice immunised with antibiotic-treated E. coli $\mathrm{O} 6: \mathrm{K}$ - were fused with mouse myeloma SP1 cells. The supernates of wells containing growing clones were tested by ELISA for antibody directed against untreated $E$. coli O6:K-, E. coli J5, E. coli $\mathrm{O} 111$ : B4 and $S$. minnesota $\mathrm{Re} 595$ as described. The antibody-producing clones were subcloned by limiting dilution and $3 \times 10^{6}$ cells were injected intraperitoneally (i.p.) into normal mice which had been primed 7 days before by i.p. injection of $0.5 \mathrm{ml}$ of 2,6 , 10, 14-tetramethyl pentadecane (Pristane; Sigma). The ascitic fluids obtained were collected aseptically and stored at $-20^{\circ} \mathrm{C}$. Antibody isotyping was performed with the Monoclonal Antibody Isotyping Kit I (HRP/ABTS, Pierce Chemical Co., Rockford, IL, USA) by the double immune diffusion technique. $\mathrm{MAb}$ from ascitic fluid was purified by protein $\mathrm{G}$ column chromatography (Immunopure plus IgG purification Kit; Pierce). ${ }^{8}$

\section{ELISA}

The binding of MAb to bacterial cells was measured by ELISAs performed as described previously. ${ }^{7} \mathrm{Vi}-$ able, untreated $E$. coli $\mathrm{O} 6: \mathrm{K}-$, E. coli $\mathrm{O} 111: \mathrm{B} 4, E$. coli $\mathrm{J} 5$ and $S$. minnesota $\operatorname{Re} 595\left(10^{7} \mathrm{cfu} / \mathrm{ml}\right.$ in coating buffer solution) were used to coat the microtitration plates (Nunclon; Nunc, Denmark) and the reactivity was measured spectrophotometrically at $492 \mathrm{~nm}$ with a spectrophotometer (Easy Beam, STL-Lab Instrument, Innsbruck, Austria) and peroxidase labelled goat anti-mouse conjugates (BioRad Laboratories, Milan, Italy). ODs below 0.2 were considered negative. Endpoint titres in ELISA at OD 0.7 were calculated by linear regression with a spreadsheet computer programme and expressed as $\log _{2}$ dilution factor (DF). ${ }^{9}$

\section{Immunoblotting}

Proteins of untreated $E$. coli $\mathrm{O} 6: \mathrm{K}$ - were resolved by polyacrylamide gel electrophoresis under reducing conditions in slab gels. ${ }^{10}$ The proteins were transferred to nitrocellulose paper ${ }^{11}$ and strips were incubated for $18 \mathrm{~h}$ at room temperature with ascitic fluid to link antibodies. The reactivities were detected by enhanced chemiluminescence (ECL, Amersham International PLC, Arlington Heights, IL, USA), as described previously. ${ }^{12}$

In further experiments, protein $(1 \mathrm{mg} / \mathrm{ml})$ of untreated $E$. coli $\mathrm{O} 6: \mathrm{K}$ - was digested with proteinase $\mathrm{K}$ $(2.5 \mu \mathrm{g} / \mathrm{ml})$ for $1 \mathrm{~h}$ and then transferred to nitrocellulose by electrophoresis.

\section{Bactericidal assay}

The bactericidal activity of ascitic fluids was estimated as described..$^{13}$ A $100-\mu 1$ sample of $E$. coli O6:K$\left(5 \times 10^{3} \mathrm{cfu} / \mathrm{ml}\right)$ was added to $100 \mu \mathrm{l}$ of purified MAb $(5 \mu \mathrm{g} / \mathrm{ml})$ in the presence of $200 \mu$ l of guinea-pig serum as complement source. After incubation for $45 \mathrm{~min}$ at $37^{\circ} \mathrm{C}$ in a shaking water bath, $100 \mu \mathrm{l}$ of the mixture was plated on blood agar and incubated overnight at $37^{\circ} \mathrm{C}$. The MAb dilution giving $50 \%$ bacterial killing was considered to be the bactericidal titre. Mouse SP1 myeloma-inducing ascitic fluid and guinea-pig serum alone were used as controls.

\section{In-vivo protection experiments}

Ninety female 6-8-week-old BALB/c mice (Nossan, Correzzana, Italy) of average weight $25 \mathrm{~g}$, were used. The mice were housed in groups of 10 and provided with food (Standard pellets, Dottori Piccioni Laboratories, Gessate, Italy) and water ad libitum. In passive protection experiments, 2, 4 and $8 \times$ LD50 doses of live $E$. coli $\mathrm{O} 6: \mathrm{K}$ - and $E$. coli $\mathrm{O} 111: \mathrm{B} 4$ (the LD50 for these strains was $3 \times 10^{7} \mathrm{cfu} /$ mouse and $1 \times 10^{8} \mathrm{cfu} /$ mouse respectively) were injected into mice 90 min. after i.p. injection of $\mathrm{MAb}(5 \mu \mathrm{g} /$ mouse $)$. Ten female BALB/c mice given sterile saline instead of $\mathrm{MAb}$ served as the control group. Mice were checked daily for 7 days and deaths were recorded. 


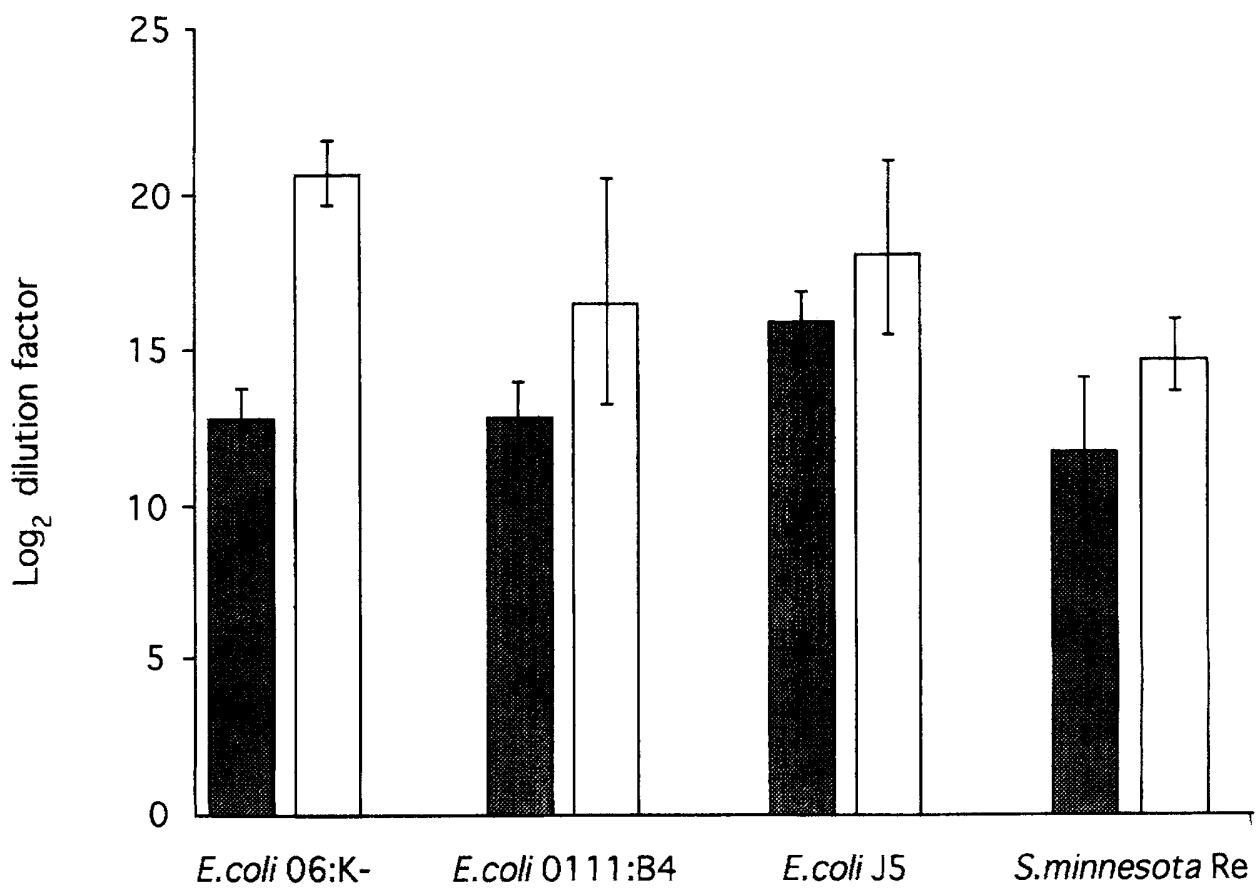

Fig. 2. Reactivity of sera from control mice and MAb MT $1 \mathrm{~F}$ investigated in ELISA with $E$. coli $\mathrm{O} 6: \mathrm{K}-$, E. coli $\mathrm{O} 111$ :B4, E. coll J5 and S. minnesota Re595. Control sera $\mathbf{\square}$; MT 1F $\square$.

\section{Statistical analysis}

Data obtained after bacterial challenge were analysed with the $\chi^{2}$ test. Data obtained in ELISA were expressed as the mean DF and the SD of three independent experiments done in duplicate; $p$ values $<0.005$ were considered significant.

\section{Results}

\section{MAb characterisation}

More than 100 hybrid clones obtained by fusing splenocytes of mice immunised with antibiotic-treated E. coli with SP1 plasmacytoma cells were studied. The MAbs were first screened by ELISA and then immunoblotted for their reactivity to untreated $E$. coli $\mathrm{O} 6: \mathrm{K}-$. Mice immunised with antibiotic-treated $E$. coli O6:Kpresented a different pattern of antibody response from that of mice immunised with untreated $E$. coli O6:K-. Therefore, among the MAbs reacting with structures of $E$. coli $\mathrm{O} 6: \mathrm{K}-$, one was selected (MT 1F) that bound to a bacterial antigen recognised only by the sera of mice immunised with antibiotic-treated bacteria.

MT $1 \mathrm{~F}$, isotype $\mathrm{IgG}_{1}$ as determined by the double immunodiffusion technique, reacted specifically with a $12-\mathrm{kDa}$ antigen of the untreated E. coli O6:K-. To determine whether the antigen was a bacterial protein or a lipopolysaccharide (LPS), an immunoblot analysis was performed on an antigenic preparation of proteinase K-digested E. coli O6:K-. After the enzymic digestion of bacterial proteins, no antigen-antibody reaction could be detected, thus indicating that the 12$\mathrm{kDa}$ antigen reacting specifically with MT $1 \mathrm{~F}$ was a protein (fig. 1).

To determine whether MT $1 \mathrm{~F}$ cross-reacted with other gram-negative strains, the binding of the $\mathrm{MAb}$ to whole bacterial cells was investigated by ELISA. The MAb presented a significantly higher reactivity (DF $>20$ ) against untreated E. coli O6:K- than that of sera from mice immunised with antibiotic-treated E. coli $(\mathrm{DF}=13.9, \mathrm{p}<0.001)$ (fig. 2). Furthermore, the MAb bound also to E. coli O111:B4, E. coli J5 and $S$. minnesota $\mathrm{Re} 595$ (DF $16 \cdot 4,17 \cdot 8$ and 14.5 respectively).

\section{Protection studies}

The protective capacity of MT $1 \mathrm{~F}$ towards lethal challenges with live homologous or heterologous bacterial strains was investigated. In a pilot experiment, several dilutions of $\mathrm{MAb}$ (from 1 to $10 \mu \mathrm{g} / \mathrm{ml}$ ) were injected into mice $90 \mathrm{~min}$ before lethal challenge $(2 \times \mathrm{LD} 50)$ with $E$. coli $\mathrm{O} 6: \mathrm{K}-$. The best protection pattern was observed with $5 \mu \mathrm{g}$ of the $\mathrm{MAb} / \mathrm{ml}$. Therefore, in the following experiments, nonimmunised mice were given $5 \mu \mathrm{g} / \mathrm{ml}$ of MAb MT $1 \mathrm{~F}$ by i.p. injection and challenged $90 \mathrm{~min}$ later with $2 \times$ LD50, $4 \times$ LD50 and $8 \times$ LD50 of either $E$. coli O6:K- or E. coli O111:B4. A group of mice given sterile saline instead of $\mathrm{MAb}$ and subsequently given the same lethal doses of bacteria by i.p. injection acted as the control.

The onset of mortality in the control group was observed after $4 \mathrm{~h}$, and within $24 \mathrm{~h}$ all control mice ( 30 animals) were dead. In contrast, in mice passively immunised with MT $1 F$ and challenged with $4 \times$ LD50 and $8 \times \mathrm{LD} 50$ of $E$. coli $\mathrm{O} 6: \mathrm{K}$-, the onset of mortality was delayed for six of 10 mice given $4 \times$ LD50 and for two of 10 mice given $8 \times$ LD50 until $24 \mathrm{~h}$, but all these mice died within $48 \mathrm{~h}$. However, of the 10 mice challenged with $2 \times$ LD50 E. coli O6:K-, two died in the first $24 \mathrm{~h}$, whereas the other eight survived and remained healthy 7 days later. 


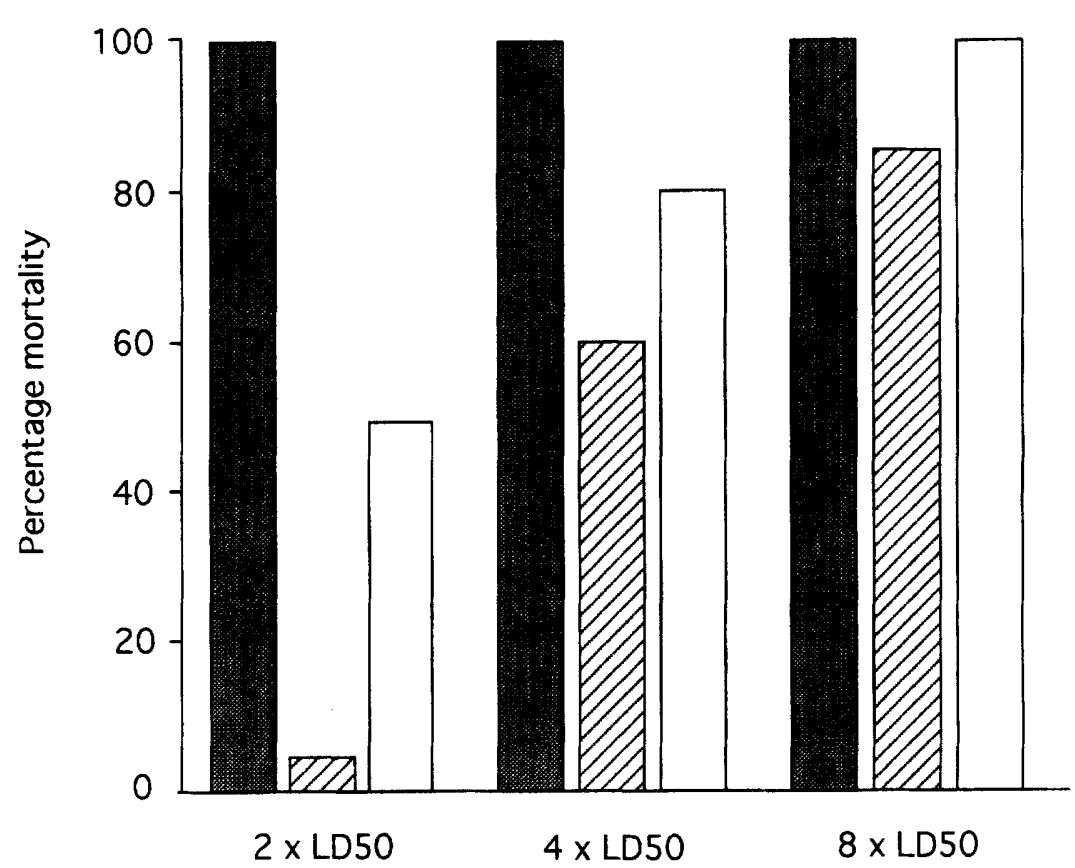

Fig. 3. The mortality of BALB/c mice after challenge with different lethal doses $(2,4,8 \times$ LD50) of live $E$. coli $\mathrm{O} 6: \mathrm{K}$ - and $E$. coli O111:B4. Control mice $\mathbf{\square}$; mice protected with MT $1 \mathrm{~F}$ and challenged with $E$. coli $\mathrm{O} 6: \mathrm{K}-囚$; mice protected with MT $1 \mathrm{~F}$ and challenged with $E$. coli O111:B4 $\square$

In the experiments in which the mice were challenged with $2 \times \mathrm{LD} 50$ of $E$. coli $\mathrm{O} 111: \mathrm{B} 4,50 \%$ of the mice $(\mathrm{n}=10)$ died within $24 \mathrm{~h}$, whereas the remainder survived. Two of 10 mice survived a challenge of $4 \times$ LD50 whereas with a challenge of $8 \times$ LD50 all mice $(n=10)$ died within $24 \mathrm{~h}$ (fig. 3).

\section{Bactericidal assay}

The complement activating capacity of MT $1 \mathrm{~F}$ was investigated. In the presence of $50 \%$ guinea-pig serum only, no bacterial killing was observed. Similarly, the addition of SP1 mouse myeloma-induced ascitic fluid to the reaction mixtures induced no bacterial death. However, MT 1F exerted bactericidal activity against live $E$. coli $\mathrm{O} 6$ : K- with a bactericidal titre $>100$.

\section{Discussion}

$E$. coli is the commonest cause of gram-negative bacteraemia and, despite appropriate treatment with new and potent antibiotics, the incidence of gramnegative bacteraemia is increasing. The possibility of an immunological approach to treatment of these infections has long been envisaged. ${ }^{14,15}$

Encouraging results in terms of reduction of mortality and morbidity in man have been obtained through the administration of plasma rich in antilipopolysaccharide (LPS) antibodies. ${ }^{16,17}$ Antibodies directed to LPS, lipid A and core regions of LPS as well as antibodies to epitopes located on outermembrane proteins have been shown to exert a protective effect in animals. ${ }^{3}$

In a previous study we demonstrated that passive transfer of hyperimmune serum from mice immunised with antibiotic-treated bacteria was capable of pro- tecting normal animals against viable homologous and heterologous lethal bacterial challenges to a greater degree than did serum from mice immunised with untreated bacteria. ${ }^{5}$ These results suggested that antibiotic treatment induced changes in the immunogenicity of the bacterial cell-surface components, leading to an enhanced production of antibodies to epitopes that were better exposed after antibiotic treatment. ${ }^{18-20}$

In this study, the previous work was extended and MAbs were produced from the spleens of mice immunised with $0.5 \times$ MIC aztreonam-treated E. coli O6:K-. Attention was focused on MAb MT $1 \mathrm{~F}$ of $\mathrm{IgG}_{1}$ isotype, which reacted with a cell-surface determinant of $12 \mathrm{kDa}$ on untreated $E$. coli $\mathrm{O} 6: \mathrm{K}$ - cells. This reactivity was revealed in Western immunoblot analysis only with the sera pooled from mice immunised with antibiotic-treated bacteria. ${ }^{5}$ The treatment of $E$. col $i$ with proteinase $\mathrm{K}$ resulted in the loss of MAb binding, thus indicating a reaction of the $\mathrm{MAb}$ to protein components, but not to other bacterial structures such as LPS.

MT $1 \mathrm{~F}$ showed protection against lethal challenge with two different $\mathrm{O}$-serotypes of $E$. coli and the protective efficacy depended on the number of bacteria used for challenge. To our knowledge, this is the first report of a MAb of $\operatorname{IgG}_{1}$ isotype, raised against a bacterial antigenic determinant expressed after antibiotic treatment, having a protective capacity. Because of the reactivity of MT $1 \mathrm{~F}$ expressed in ELISA against whole bacterial cells, which was abolished in immunoblotting experiments after enzymic digestion of bacterial proteins, it seems probable that MT 1F recognised protein structures on the bacterial surface. This hypothesis is supported by the observation that the accessibility of the major outer-membrane proteins 
was enhanced when members of the Enterobacteriaceae were grown in the presence of $\beta$-lactam antibiotics. ${ }^{20}$ It is possible that epitopes on proteins on the outer surface of $E$. coli were better exposed after antibiotic treatment, thereby permitting the immune system to produce a different antibody response.

Our data seem to show that the epitope recognised by MT $1 \mathrm{~F}$ is present on different serotypes of some members of the Enterobacteriaceae. Hofstra et al.,${ }^{21}$ in crossed immuno-electrophoretic studies, showed cross-reactivity among OMPs of members of the Enterobacteriaceae. Further studies showed that antibodies to OMPs were protective in experimentally induced infections in mice. ${ }^{22,23}$ In ELISA experiments, reactivity of the MAb against whole $E$. coli J5, E. coli O111:B4 and $S$. minnesota Re595 was observed. Therefore, it is possible that if MT $1 \mathrm{~F}$ recognises common bacterial epitopes, it might bind to cell-wall determinants of heterologous strains and offer a degree of protection against lethal challenges of bacteria. The

\section{References}

1. Rozenberg-Arska M, Visser MR. Infectious disease therapy in the 1990s. Where are we heading? Drugs 1992; 43: 629-636.

2. Ziegler EJ, Fischer CJ, Sprung CL et al. Treatment of Gramnegative bacteraemia and septic shock with HA-1A human monoclonal antibody against endotoxin. A randomized, double-blind, placebo-controlled trial. N Engl J Med 1991; 324: $429-436$.

3. McCabe WR, De Maria A, Berberich H, Johns MA. Immunization with rough mutants of Salmonella minnesota: protective activity of IgM and IgG antibody to Re595 (Re Chemotype) mutant. J Infect Dis 1988; 158: 291-300.

4. Raponi G, Keller N, Overbeek BP, Rozenberg-Arska M, Torensma R, Verhoef J. Immunization of mice with antibiotic-treated Escherichia coli results in enhanced protection against challenge with homologous and heterologous bacteria. $J$ Infect Dis 1991; 163: 122-127.

5. Raponi G, Lun MT, Lorino G et al. Reactivity and protective capacity of a polyclonal antiserum derived from mice immunized with antibiotic exposed Escherichia coli. $J$ Antimicrob Chemother 1993; 31: 117-128.

6. Fazekas De St Groth S, Scheidegger D. Production of monoclonal antibodies: strategy and tactics. J Immunol Methods 1980; 35: 1-21.

7. Overbeek BP, Schellekens JFP, Lippe W, Dekker BAT, Verhoef J. Carumonam enhances reactivity of Escherichia coli with mono- and polyclonal antisera to rough mutant Escherichia coli J5. J Clin Microbiol 1987; 25: 1009-1013.

8. Eliasson M, Olsson A, Palmcrantz E et al. Chimeric IgGbinding receptors engineered from staphylococcal protein A and streptococcal protein G. J Biol Chem 1988; 263: $4323-4327$.

9. Schellekens J, Benne CA, De Zeeuw GR, Rozenberg-Arska M, Verhoef J. Natural occurring IgG and IgM antibodies to gram-negative bacteria and lipopolysaccharides in human sera. Serodiagn Immunother Infect Dis 1988; 2: 433-444.

10. Laemmli UK. Cleavage of structural proteins during the assembly of the head of bacteriophage T4. Nature 1970; 227: $680-685$.

11. Towbin H, Staehelin T, Gordon J. Electrophoretic transfer of proteins from polyacrylamide gels to nitrocellulose sheets: procedure and some applications. Proc Natl Acad Sci USA $1979 ; 76: 4350-4354$.

12. Andrews AT. Electrophoresis: theory, techniques, and bio- mechanism of protection observed in this study was probably due to an improvement of the opsonic capacity of the passively immunised mice, because it was observed that MAb MT $1 F$ had bactericidal capacity in vitro against live E. coli.

In conclusion, the present findings confirm that treatment of $E$. coli with antibiotics is capable of inducing qualitative changes in the antigenic presentation of the bacterial surface components. These structures may induce a protective immune response towards homologous and heterologous E. coli strains. Although at an early stage, the experimental approach adopted in this study appears to be capable of directing at the molecular level the complexity of the immune response to antibiotic-treated bacteria, thus opening up the possibility of identifying immunogenic molecules of biological and clinical interest.

This work was partially supported by a grant from the "National Research Council" (CNR) targeted project "Prevention and Control Disease Factors", subproject "Causes of Infectious Diseases". chemical and clinical applications, 2nd edn. In: Peacocke AR, Harrington WF (eds) Monographs on physical biochemistry. Oxford, Clarendon Press. 1986.

13. Brodeur BR, Tsang P, Larose Y. Parameters affecting ascites tumour formation in mice and monoclonal antibody production. J Immunol Methods 1984; 71: 265-272.

14. Calandra T, Glauser MP, Schellekens J, Verhoef J and SwissDutch Immunoglobulin Study Group. Treatment of gramnegative septic shock with human IgG antibody to Escherichia coli $\mathrm{J} 5$ : a prospective, double-blind, randomized trial. $J$ Infect Dis 1988; 158: 312-319.

15. Chedid L, Parant M, Parant F, Boyer F. A proposed mechanism for natural immunity to enterobacteria pathogens. $J$ Immunol 1968; 100: 292-301.

16. Ziegler EJ, McCutchan JA, Fierer J et al. Treatment of gramnegative bacteraemia and shock with human antiserum to a mutant Escherichia coli. $N$ Engl J Med 1982; 307: $1225-1230$.

17. Johns M, Skehill A, McCabe WR. Immunization with rough mutants of Salmonella minnesota IV. Protection by antisera to $\mathrm{O}$ and rough antigens against endotoxin. $J$ Infect Dis 1983; 147: 57-67.

18. Leying H, Suerbaum S, Kroll HP, Karch H, Opferkuch W. Influence of beta-lactam antibiotics and ciprofloxacin on composition and immunogenicity of Escherichia coli outer membrane. Antimicrob Agents Chemother 1986; 30: $475-480$.

19. Zak O, Kradolfer F. Effect of subminimal inhibitory concentrations of antibiotics in experimental infections. Rev Infect Dis 1979 ; 1: 862-879.

20. Overbeek BP, de Vos NM, Schellekens JFP, Rozenberg-Arska $M$, Verhoef J. Beta-lactam antibiotics enhance the building of antibodies to outer membrane, non LPS antigenic structures in Enterobacteriaceae. Serodiagn Immunother Infect Dis $1989 ;$ 3: 175-183.

21. Hofstra H, van Tol MJD, Dankert J. Cross-reactivity of major outer membrane proteins of Enterobacteriaceae, studied by crossed immunoelectrophoresis. J Bacteriol 1980; 143 : 328-337.

22. Màkelà $\mathrm{PH}$, Kuusi N, Nurminen $\mathrm{M}$, Saxen $\mathrm{H}$, Valtonen $\mathrm{M}$. Porins: the major outer membrane proteins of enteric bacteria as protective antigens. Semin Infect Dis 1982; 4 : $360-365$.

23. Udhaiyakumar V, Muthukkaruppan VR. Protective immunity induced by outer membrane proteins of Salmonella typhimurium in mice. Infect Immun 1987; 55: 816-821. 